\title{
Production and Growth of Pulses in Telangana State: An Economic Analysis
}

\author{
Raju Guntukula \\ School of Economics, University of Hyderabad, Hyderabad, Telangana, India \\ Corresponding author: rajug@uohyd.ac.in
}

\begin{abstract}
Pulses are the most important for Indian diet and the principal source of protein for the poor people and the vegetarians. India is at the high among all the major pulse producing nations in the world. The present investigation is an attempt to examine the pattern of growth and instability in the cropped area, production and productivity of major pulse crops in Telangana state. The annual time series of data form the period 1980 to 2015 relating to the area, production and productivity of major pulse crops have been used to compute growth rates, standard deviation and coefficient of variation to realize the objectives. The results of the study reveal that there have been positive changes in the area of pulse crops. The annual average growth rate in the area was estimated to be $0.05 \%, 0.01 \%,-0.03 \%$ and $0.02 \%$ in Bengal gram, black gram, green gram and red gram respectively. The production growth rate in the same pulse crops was presented to be $0.83 \%, 0.20 \%, 0.13 \%$ and $0.17 \%$ as the average annual growth rate in the State. The productivity growth rate for these crops was further assessed to be $0.18 \%, 0.13 \%, 0.10 \%$ and $0.15 \%$, respectively. The instability in the area was observed to be high in green gram followed by red gram and bengal gram and minimum in black gram. Similarly, instability in productivity was also found to be high in bengal gram and minimum in green gram. Further, variability in production was also observed to be maximum in bengal gram followed by the red gram, and green gram and minimum in black gram, respectively.
\end{abstract}

Keywords: Growth scenario, area, production, productivity and instability.

Pulse crops are grown in more than 171 countries in the world. The world's major producers of pluses are India (23.1\%), China (12.08\%), Myanmar (7.57\%), Canada $(6.7 \%)$ and Brazil $(4.03 \%)$ which jointly account for half of the world's total production (Shingne et al. 2017). India accounts for 33\% of the world's cultivated area under pulses. India is the leading producer of pulses in the world in quantity and also it is a rare country that cultivate varieties of pulse crops which none of the other nations in the world grow. Once a net exporter and currently India has turned into one of the principal importers of pulses. In addition, India is the largest consumer of pulses in the world (Meena et al. 2016). Pulses are the principal source of protein for the poor people and the vegetarians who set up the majority of Indian population and the traditional cropping pattern that always incorporated a pulse crop both as a mixed crop and also in the rotation. Pulses popularly known as "Poor man's meat" and "rich man's vegetable", contribute considerably to the food security of the country (Sing et al. 2015). Given the nutritious importance of pulses, this study argues that a growth of pulses production is important to meet the current protein gap in India. Growing pulses also contribute to the increase in soil fertility in terms of greater organic matter content and by fixing atmospheric nitrogen to enrich soil fertility, thereby growing the productivity of the successive crop (Sadasivan, 1989). Pulses are one of the core segments of Indian agriculture next to cereals and oilseeds. India grows a diversity of pulse crops such as Chickpea, Pigeon pea, Greengram, Blackgram, Lentils and dry peas under a widespread range 
of agro-climate settings. The production of overall pulse crops in India is presently around 17 million tonnes covering an area of almost 23 million hectares and the majority of which fall under rainfed, harsh environments and resource poor that are often prone to drought and other weather extremes. Pulses are less chosen by farmers because of larger risk and low remuneration than cereals; thus, the production of the pulse is sufficiently low. Due to the stagnant production of pulses, the net availability for per-capita consumption has come down from $60 \mathrm{gm} /$ day in 1951 to $31 \mathrm{gm} /$ day in 2008. To meet the demand of pulses consumption, India is currently importing almost 3 million tonnes of variety of pulses.

The production of pulses, which was 8.42 million tonnes in 1952, had increased to 19.25 million tonnes in 2014. Similarly, the productivity increased from 448 kilograms per hectare in 1952 to $764 \mathrm{~kg} /$ ha in 2013-14 (ES, 2016). The important states for pulses production are Madhya Pradesh, Uttar Pradesh, Maharashtra, Rajasthan, Andhra Pradesh, Karnataka, Bihar Gujarat, Chhattisgarh, Orissa, Jharkhand and Telangana, which are jointly accountable for more than $80 \%$ of the India's total pulses production.

In Telangana state, the total area under pulses was 4.08 lakh hectares in 2014-2015. Among the pulse crops, the maximum area was under Redgram, which covered 2.49 lakh hectares during 201516 followed by Greengram, Bengalgram and Blackgram which occupied 1.11, 0.70 and 0.32 lakh hectares of land respectively. Overall, pulses covered about 4.72 lakh hectare of the area during the same period which was about $50 \%$ less than that in the year 2000-2001. The overall production of pulses during 2013-14 was 4.65 lakh tonnes, which was about 2.66 lakh hectares during 2000-2001. Recently, in Telangana state, pulses and soybean have already crossed the long term normal acreage under these crops as some percentage of cotton area was shifted mostly for these crops (Guntukula, 2017). However, soybean was sown in 2.70 lakh hectares against the long term normal cropped area of 2 lakh hectares. The present study was undertaken to examine the growth and patterns in area, production and productivity of pulses in Telangana state and also to examine variability in the area, production and productivity of pulse crops.

\section{DATA AND METHODOLOGY}

The state of Telangana was chosen purposively as it is a major pulse producing state in India. This study depends on secondary data gathered from various published sources. Data on the area, production and productivity were collected from the Directorate of Economics \& Statistics (DE\&S), Government of Telangana, Agricultural Statistics at a Glance 2016 and other official sources. Data were collected for four major pulses (Red gram, Bengal gram, Black gram and Green gram) in the state due to the significance in consumption preference form the period 1980-81 to 2015-16. Further, the study period was divided into four periods; i.e. 1980-81 to 199091, 1991-92 to 2000-01 and 2001-02 to 2015-16 and overall period. To estimate the growth rates of major pulse crops with respect to area, production and productivity, average annual growth rate (AAGR) has been used for further analysis. Likewise, to examine the instability or variability with respect to area, production and productivity of the crops, mean, standard deviation (SD) and coefficient of variation $(\mathrm{CV})$ were worked out for the four different periods.

\section{RESULTS AND DISCUSSION}

\section{Growth and Instability of area under selected pulses in Telangana state}

The time period taken for the analysis was from 1980-81 to 2015-16 which was divided into three periods i.e. period one (1980-81 to 1990-91), period two (1991-92 to 2000-01) and period three (2001-02 to 2015-16). The trends in area under major pulse crops of the Telangana state are presented in the figure below. Similar to all India level area under pulses, the state area under pulses is almost showing the same trends. Among the pulses, green gram crop has been decreasing highly over the period of time compared to other pulse crops.

Bengal gram and black gram are almost moving together over the period time, showing a stable linear trend, however, after 2001-02 these crops are displaying a slight increase in the area of pulses. Interestingly, red gram crop is showing an increasing trend in area under pulses over the period from 1980 to 2015. The reasons for declining green gram area in Telangana may be due to extensive rice and wheat cropping system replacing pulses 


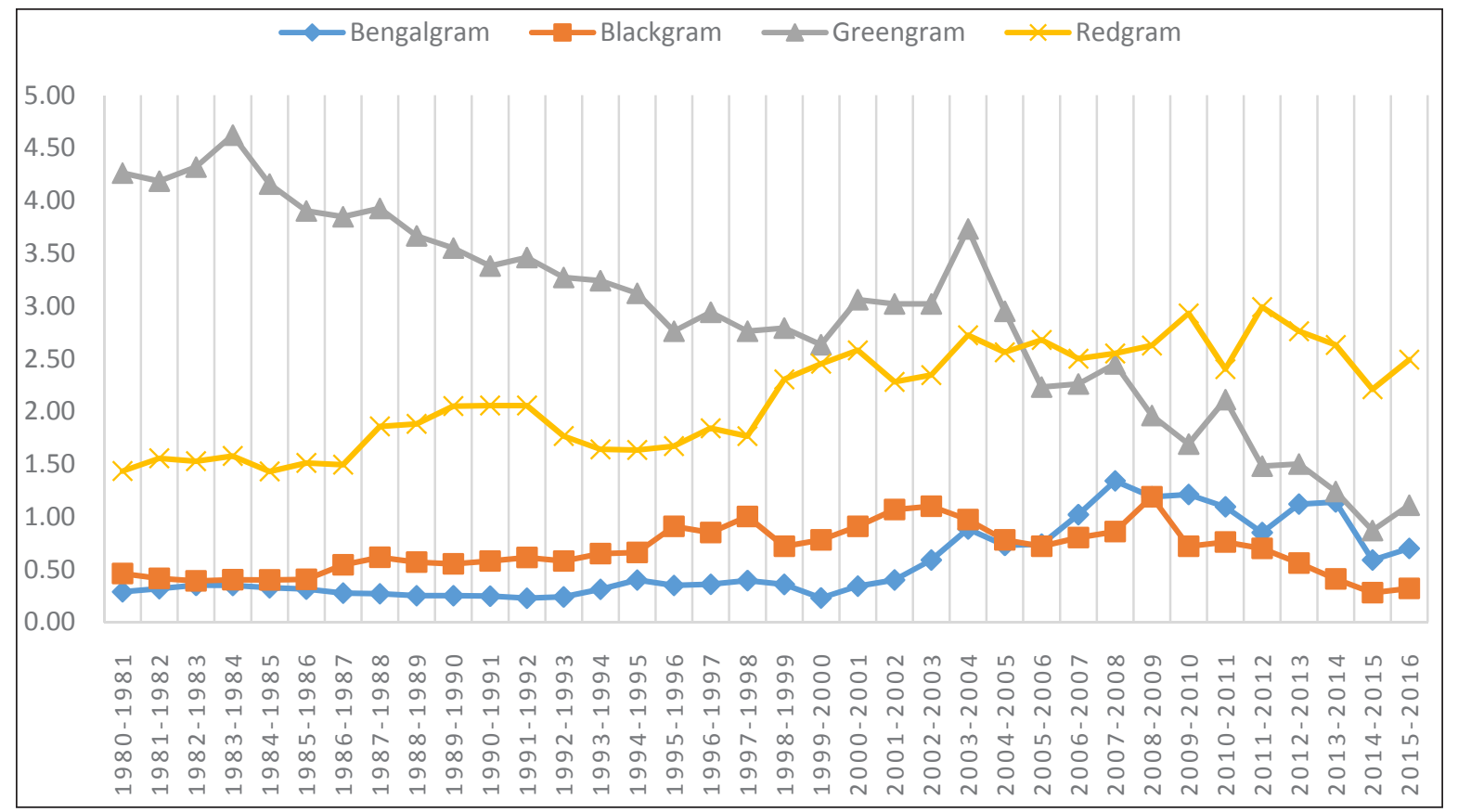

Fig. 1: Trends in area under Pulses in Telangana 1980-81 to 2015-16 (lakh hectares)

Table 1: Growth and Instability of area under Pulses (Area in lakh hectares)

\begin{tabular}{ccccc}
\hline \multicolumn{5}{c}{ Average Annual Growth rate in area under Pulses } \\
\hline Pulses & Period I & Period II & Period III & Overall Period \\
\hline Bengal gram & -0.1 & 0.07 & 0.08 & 0.05 \\
Black gram & 0.03 & 0.06 & -0.06 & 0.01 \\
Green gram & -0.02 & -0.01 & -0.05 & 0.03 \\
Redgram & 0.04 & 0.03 & 0.01 & 0.02 \\
\hline & Instability (SD) in area under Pulses (Figures in Parenthesis are Coefficient of Variation) & $0.35(62.7)$ \\
Bengal gram & $0.04(13.1)$ & $0.07(20.6)$ & $0.28(30.5)$ & $0.23(34.3)$ \\
Green gram & $0.09(17.9)$ & $0.14(18.9)$ & $0.27(36.5)$ & $0.98(33.5)$ \\
Red gram & $0.37(9.2)$ & $0.27(9.0)$ & $0.82(38.9)$ & $0.22(8.6)$ \\
\hline
\end{tabular}

Source: Directorate of Economics and Statistics, Government of Telangana.

and farmers' choice towards more remunerative crops. The results of the estimated average annual growth rate (AAGR), standard deviation (SD) in area of various pulses for Telangana were presented in the Table 1.

It can be seen from the (Table 1) that area of Bengal gram presented a negative growth rate of $-0.1 \%$ in period I, whereas it showed positive growth rates of $0.07,0.08$ and $0.05 \%$ respectively in period II, period III \& overall period of Telangana state as a whole. Moreover, it can be seen that area of Black gram presented a positive growth rate of 0.03 and $0.06 \%$ in period I and period II respectively, whereas it showed a negative growth rate of $-0.06 \%$ in period III. However, Green gram presented a negative growth rate in all the three periods and also in overall period. But, Red gram area exhibited positive growth rates of $0.04,0.03,0.01$ and $0.02 \%$ respectively in period I, II, III and overall period.

An analysis of instability in the area under major pulse crops are displayed in Table 1. The two major statistical techniques used are the standard deviation, which gives an absolute measure of instability, and coefficient of variation, which indicates the relative change in instability. It is evident that among the pulse crops under study, the instability in area was observed to be maximum in green gram (0.37 lakh hectares), followed by red 
gram (0.24 lakh hectares), black gram (0.09 lakh hectares) and minimum in case of Bengal gram (0.04 lakh hectares) during Period I. It was further seen that in period II, the maximum variability was found in the case of red gram and minimum in bengal gram. The maximum instability was observed in case of green gram followed by bengal gram during period III. In the overall period, the maximum instability was again observed in the case of green gram and the minimum was 0.23 lakh hectare in black gram.

The table further shows that in terms of percentage (Figures in parenthesis), the instability was observed to be high in bengal gram during period I and overall period. In the case of black gram, the maximum instability was observed during period III. Likewise, in the case of green gram, the maximum instability was observed to be high in period III $(38.9 \%)$. In the overall period the maximum instability was registered in case of red gram. The high instability in the area under pulse crops may be due to a shortage of soil moisture condition and natural factors.

\section{Growth and Instability of production of selected pulses in Telangana state}

After analyzing the area of trends of pulse crops, the trends in production of selected pulses growth rates were estimated. It can be seen from Fig. 2 that among the pulse crops, Green gram production has been decreasing high over the period of time compared to other pulses crops. Bengal gram and Red gram are almost moving together over the period time showing unstable linear trend, however, these crops are displaying a slight increase in the production of pulses. Interestingly, black gram crop production is showing an increasing trend over the period from 1980 to 2015.

The assessed growth rates and standard deviation of production of major pulses of Telangana state are presented in Table 2 . The production of bengal gram presented a positive growth rate of $0.86 \%$ in period I, whereas it showed positive growth rates of $0.76,0.93$ and $0.83 \%$ in period II, III \& overall period respectively. Moreover, it can be seen that production of Black gram presented a positive growth rate of $0.33,0.16,0.10$ and $0.20 \%$ in period I, II, III and overall period respectively. However, Green gram crop production presented a positive growth rate in all three periods and also in overall period. Similarly, red gram production showed positive growth rates of $0.09,0.36,0.10$ and $0.17 \%$ in period I, II, III and overall period respectively. The reasons for the increase in pulses production in the state may be due to the following reasons; Incorporation of short period pulses to make different production systems profitable and increase soil health. The increase in pulses production could be due to an increase in the price of pulses in the market and decent marketing facility.

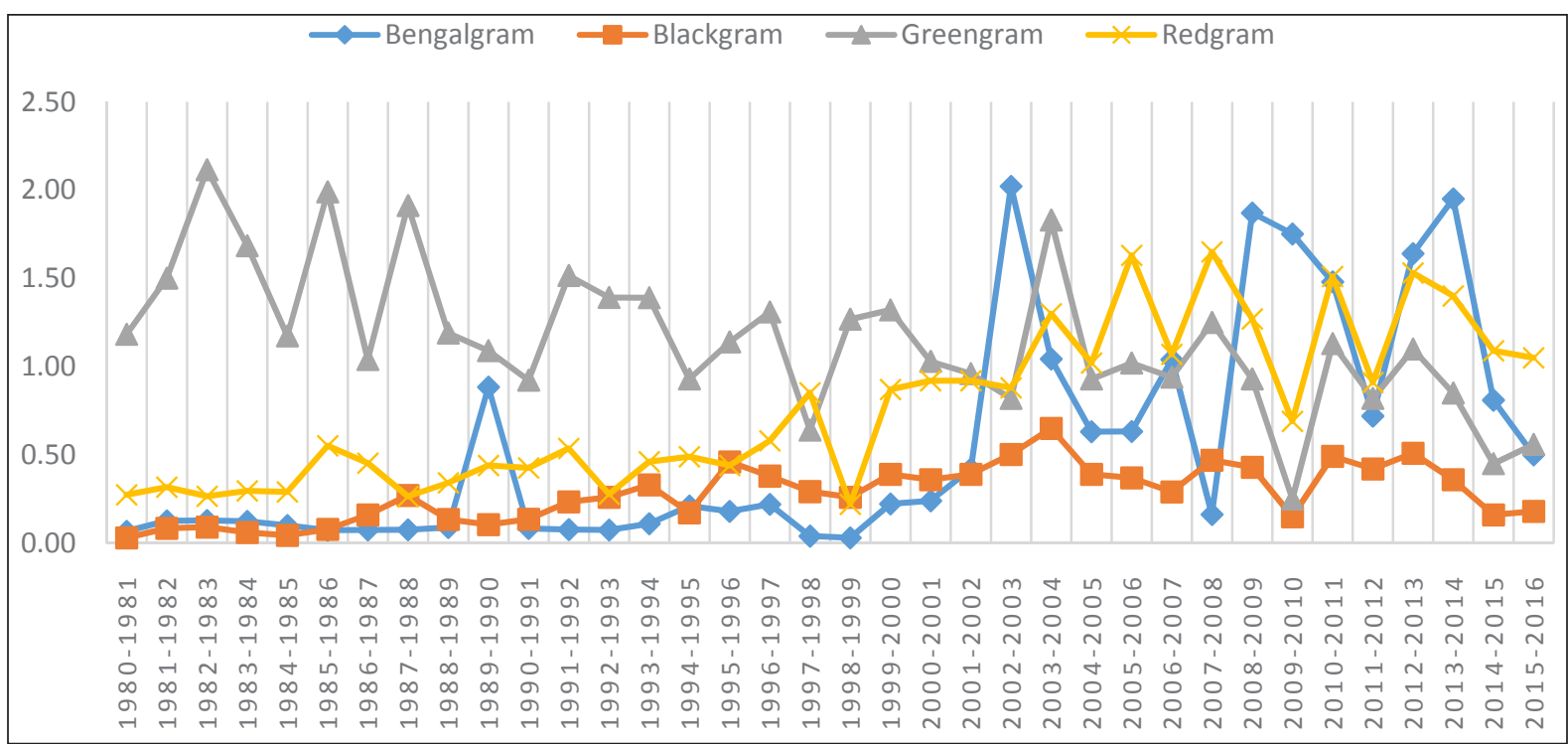

Fig. 2: Trends in Production of Pulses in Telangana 1980-81 to 2015-16 
Table 2: Growth and Instability of Pulses production in Telangana (Production in lakh tonnes)

\begin{tabular}{ccccc}
\hline \multicolumn{5}{c}{ Average annual growth rate of Pulses Production } \\
\hline Pulses & Period I & Period II & Period III & Overall Period \\
\hline Bengal gram & 0.86 & 0.76 & 0.93 & 0.83 \\
Black gram & 0.33 & 0.16 & 0.10 & 0.20 \\
Green gram & 0.06 & 0.03 & 0.22 & 0.13 \\
Red gram & 0.09 & 0.36 & 0.10 & 0.17 \\
\hline \multicolumn{6}{c}{ Instability (SD) of Pulses Production (Figures in Parenthesis are Coefficient of Variation) } \\
\hline Bengal gram & $0.24(144)$ & $0.08(58.6)$ & $0.62(55.9)$ & $0.63(115)$ \\
Black gram & $0.07(61.3)$ & $0.09(27.4)$ & $0.14(36.8)$ & $0.16(57)$ \\
Green gram & $0.42(29.5)$ & $0.26(22.0)$ & $0.36(39.4)$ & $0.41(36)$ \\
Red gram & $0.10(27.0)$ & $0.24(43.2)$ & $0.30(25.1)$ & $0.44(58)$ \\
\hline
\end{tabular}

Source: Directorate of Economics and Statistics, Government of Telangana.

One would not be clear of instability by taking the growth rates alone. Because the growth rates can only explain the rate of growth over the period of time. Whereas, instability will judge whether the growth performance is stable (or unstable) for the period as the pertinent variable. The instability (SD in Table 2) in production was observed to be maximum in green gram (0.42 lakh tonnes), followed by bengal gram (0.24 lakh tonnes), red gram $(0.10$ lakh tonnes) and minimum in case of black gram (0.04 lakh tonnes) during Period I. It was further seen that in period II, the maximum variability was found in the case of green gram and minimum in red gram. The maximum instability was observed in case of bengal gram followed by green gram during period III. In the overall period, the maximum instability of production was observed in the case of bengal gram (0.63 lakh tonnes) and the minimum was 0.16 lakh tonnes in black gram.

Further, the Table 2 shows that in terms of percentage change, the instability was observed to be high in bengal gram during the period I and overall period. In case of black gram, the maximum instability was observed during period I (61.3\%). Likewise, in case of green gram, the maximum instability was observed to be high in period III (39.4\%). In the overall period the maximum instability was registered in case of red gram. The high instability in the production of pulse crops may be due to high sensitivity of the crops to pests and disease and various other reasons.

\section{Growth and Instability of productivity of selected pulses in Telangana state}

The productivity of pulse crops is an important concern in India. Covering in this, an attempt has been made to analyze the productivity of major pulses in Telangana state. Trends and patterns of major pulse crops productivity are presented in Fig. 3. Green gram, red gram and black gram are moving almost together over the period of time showing a stable linear trend, however, these crops are displaying a slight increase in the productivity of pulses. Remarkably, red gram crop productivity is showing an increasing trend in the area under pulses over the period from 1980 to 2015, however, it has shown more increasing trend after the year 2000-2001.

The results of the estimated average annual growth rate and standard deviation of productivity of major pulse crops for Telangana are presented in the following Table 3 . The productivity of bengal gram presented a positive growth rate of $0.06 \%$ in period I and it also showed positive growth rates of 0.51 , 0.04 and $0.18 \%$ respectively in period II, III \& overall period. Moreover, it can be seen that production of black gram presented a positive growth rate of 0.29 , $0.04,0.07$ and $0.13 \%$ in period I, II, III and overall period respectively. However, green gram crop productivity presented a progressive growth rate in all three periods and also in overall period. In the same way, red gram productivity showed positive growth rates of $0.06,0.33,0.08$ and $0.15 \%$ in period 


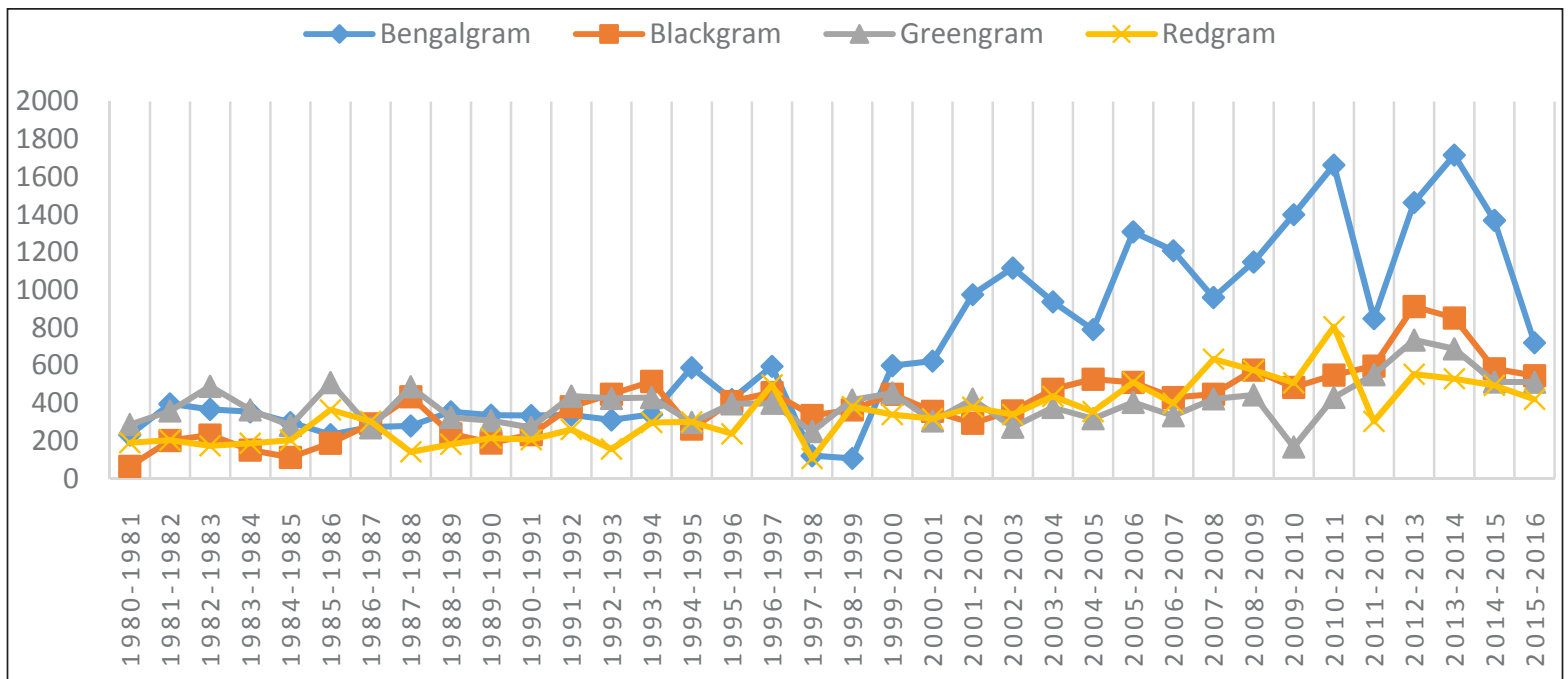

Fig. 3: Productivity trends of Pulses in Telangana 1980-81 to 2015-16

Table 3: Growth and Instability of Pulses Productivity in Telangana (Yield in kg per hectare)

\begin{tabular}{ccccc}
\hline \multicolumn{5}{c}{ Average annual growth rate of Pulses Productivity } \\
\hline Pulses & Period I & Period II & Period III & Overall Period \\
\hline Bengal gram & 0.06 & 0.51 & 0.04 & 0.18 \\
Black gram & 0.29 & 0.04 & 0.07 & 0.13 \\
Green gram & 0.08 & 0.01 & 0.11 & 0.10 \\
Red gram & 0.06 & 0.33 & 0.08 & 0.15 \\
\hline \multicolumn{5}{c}{ Instability (SD) of Pulses Productivity (Figures in Parenthesis are Coefficient of Variation) } \\
\hline Bengal gram & $55(17.5)$ & $195(48.1)$ & $308(26.2)$ & $466(67)$ \\
Black gram & $96(45.3)$ & $73(18.2)$ & $161(30)$ & $185(46)$ \\
Green gram & $93(25.9)$ & $71(18.4)$ & $147(33.6)$ & $117(30)$ \\
Red gram & $63(29.3)$ & $110(38.1)$ & $130(26.9)$ & $159(46)$ \\
\hline
\end{tabular}

Source: Directorate of Economics and Statistics, Government of Telangana.

I, II, III and overall period respectively. The reasons for the growth of pulses productivity in the state may be due to the following reasons: awareness of farmer about the availability of improved seeds, technical guidance, facility of irrigation, marketing facility.

The productivity variability of the major pulse crops is demonstrated in Table 3. The instability (SD) in productivity was observed to be maximum in black gram (96 kg/ha), followed by green gram (93 kg/ha), red gram (63 kg/ha) and minimum in case of bengal gram (55 kg/ha) during Period I. It was further seen that in Period II, the maximum instability in productivity was found in the case of bengal gram and minimum in green gram. The maximum instability was observed in case of bengal gram followed by black gram during Period III.
In the overall period, the maximum instability of productivity was observed in the case of bengal gram (466 kg/ha) and the minimum was $117 \mathrm{~kg} / \mathrm{ha}$ in green gram. Further, the Table 3 shows that in terms of percentage change $(\mathrm{CV})$, the instability was observed to be high in bengal gram during overall period $(67 \%)$ and period II (48.1\%). In case of black gram, the maximum instability was observed during overall period $(46 \%)$. Similarly, in case of green gram, the maximum instability in productivity was observed to be high in period III (33.6\%). In the overall period, the maximum instability in productivity was registered in case of red gram $(46 \%)$ in the state. Further, the study analyses the recent performance of the total pulses of Telangana state in the following section. 


\section{Recent performance of total pulses in Telangana state}

The total pulses comprise of bengal gram, green gram, red gram, black gram, cow gram, horse gram and other pulses. The performance of total pulses in the state in the recent period is explained in table 4. Area, production and productivity of pulses were taken for analysis from the period 2005 to 2015. The area under pulses in the state is showing a decreasing trend. Total area under pulses was found to be 7.69 lakh hectares in 2005-06 but it declined to 4.72 in 2015-16. In Telangana, pulses are cultivated on negligible and marginal or less fertile lands under rain-fed conditions. The majority of the area under pulses has no guaranteed irrigation services. However, because of the higher level of fluctuations in pulses production due to biotic and abiotic stress and lesser minimum support prices, farmers do not concentrate much on taking up the cultivation of pulse crops in the state despite greater wholesale pulse prices in the recent years. So farmers are paying attention towards cash crops like cotton, maize, oilseeds and others because of better return and lesser risk. And also the recent periods unfavorable climatic conditions are strongly affecting the area of pulses.

Table 4: Area, Production and Productivity of Total Pulses from 2005-06 to 2015-16

\begin{tabular}{cccc}
\hline Year & Area & Production & Productivity \\
\hline $2005-06$ & 7.69 & 5.53 & 719 \\
$2006-07$ & 6.86 & 3.68 & 536 \\
$2007-08$ & 7.31 & 5.16 & 706 \\
$2008-09$ & 6.64 & 4.62 & 696 \\
$2009-10$ & 7.12 & 3.37 & 473 \\
$2010-11$ & 7.57 & 4.74 & 626 \\
$2011-12$ & 6.18 & 2.96 & 479 \\
$2012-13$ & 6.11 & 4.91 & 804 \\
$2013-14$ & 5.56 & 4.65 & 835 \\
$2014-15$ & 4.08 & 2.62 & 642 \\
$2015-16$ & 4.72 & 2.47 & 520 \\
\hline
\end{tabular}

Source: Directorate of Economics and Statistics, Government of Telangana; Note: (Area in lakh hectares, Production in lakh tonnes Productivity in $\mathrm{kg}$ per hectare)

Pulse production has recorded lesser growth for the past 10 years. A perusal of the table shows that the production of total pulses was 5.53 lakh tonnes in the year of 2005-06, later it declined to 2.47 in the year of 2015-16. The pulses production performance of the state in the recent period has declined largely. The current scenario of pulses production will lead to nutritional insecurity problem in the state because of the low level of output which would lead to an increase in the price of the pulses. So, the poor people may not or may less consume compared to the normal price situation. The total pulses production during the recent period is decreasing perhaps due to the negative impacts of climate change and other factors. Further, the performance productivity of total pulses crops is presented in Table 4. An examination of the above table shows that the productivity of total pulses was $719 \mathrm{~kg} / \mathrm{ha}$ in the year 2005-06, later it declined to $520 \mathrm{~kg} / \mathrm{ha}$ in the year of 2015-16. Adverse weather conditions, unavailability of improved seeds \& other inputs, improper agronomic management, and other socioeconomic factors are perhaps the main reasons for the decreasing productivity of pulses.

\section{CONCLUSION}

Telangana is one of the important pulses growing states in the country with an area of 7 lakh hectares with a production of 4 lakh tonnes annually. The results of the study lead to the conclusion that a positive growth rate in the area of all pulses has been revealed in the state except for green gram, which has shown negative growth rate. The positive growth rate in the production of all pulse crops has been presented in the state, however, the growth rate is higher in bengal gram and low in green gram. The productivity growth rate further exposes that there has been a considerable growth in the productivity of all pulses crops. The yield of bengal gram has increased as the average annual growth rate of $0.83 \%$ in the state. However, instability in area and productivity are found to be quite high in all pulses crops, which affects the quantity of production. The major reasons for low production and yield of pulses in the state are: (a) pulses are grown under rainfed conditions; (b) they are cultivated in marginal lands and poor soils; (c) the pulses crops are grown as an intercrop or as a mixed crop. There is a need to develop such varieties of pulse crops against drought, disease and pest and also according to the appropriate climatic condition of the state. 


\section{REFERENCES}

Economic Survey, 2015-16. Government of India.

Guntukula, R. 2017. Agricultural Performance of Telangana State: An Analysis. Asian Journal of Research in Social Sciences and Humanities, 7(8): 169-181.

Meena, V.S., Sharma, S. and Dagar, V. 2016. Production and Growth in Pulses in India. Agricultural Situation in India, LXXII(2).

Sadasivan, S. 1989. Pattern of Pulses Production: An Analysis of Growth Trends. Economic and Political Weekly, A167-A180.
Shingne, S.P., Shende, N.V., Rathod, S.A., Panajwar, A.V. and Gandhre, A.P. 2017. Growth and Instability of Gram in Vidharbha region. International Journal of Information Research and Review, 4(5).

Singh, A.K., Singh, S.S., Prakash, V., Kumar, Santosh, and Dwivedi, S.K. 2015. Pulses production in India: present status, bottleneck and way forward. J. Agric. Search, 2(2): 75-83. 